Edukacja Filozoficzna 68/2019

ISSN 0860-3839

DOI: $10.14394 /$ edufil.2019.0015

ORCID: 0000-0003-2732-8391

\title{
The Faith of Abraham
}

\author{
Howard Wettstein \\ (University of California, Riverside)
}

In this paper, ${ }^{1}$ I consider the arresting biblical story known as the Akedah (literally "binding," as in the binding of Isaac by his father Abraham). What can we make of this shocking story; what can we learn from it? I am interested here not in historical/cultural analysis but rather in understanding the excruciating interaction between God, a father and a son. Not just any father and son, but God's beloved Abraham and the son who was to become the father of nations. I will conclude with remarks concerning the Bible's complete lack of defensiveness about God. By contrast with later theological discussion, the Bible often makes no attempt to justify God's ways, to explain God's reasons for the strange ways of the world or for God's own sometimes strange ways.

The Akedah is haunting. All three Abrahamic religious traditions take the story as foundational; it establishes Abraham as the father of these faiths, even the father of faith. It is not, though, a story one would read to a child before bedtime. A sensitive child might shiver at the apparent moral horror. Israeli author

This paper is based on talks given over the years at a number of institutions. An earlier version was made available on Academia.com. Thanks to all those who commented, especially to Jeff Helmreich and Joseph Almog for illuminating discussions and to Shaul Seidler-Feller for comments on the current version. 
A.B. Yehoshua argues that Abraham's blind obedience cannot have positive religious significance. Indeed it is sometimes suggested that Abraham failed God's test; commanded to murder, he was all too willing, no questions asked. Yet there is something enormously powerful, even inspirational, about the story and about Abraham. In the earlier biblical narrative of Sodom and Gomorrah, Abraham boldly confronts God (Gen. 18:23-25):

Abraham came close and said

Will you really sweep away the innocent along with the guilty?

Perhaps there are fifty innocent within the city,

Will you really sweep it away?

Will you not bear with the place because of the fifty innocent that are in

its midst?

Heaven forbid ${ }^{2}$ for you to do a thing like this,

to deal death to the innocent along with the guilty,

that it should come about: like the innocent, like the guilty.

Heaven forbid for you!

The judge of all the earth - will He not do what is just? ? $^{3}$

Commanded to sacrifice Isaac, where stunned incredulity seems much more in order, Abraham is strangely silent, even passive; then he arises early-the Hebrew suggests something close to eagerness, ${ }^{4}$ and sets off toward Mt. Moriah with Isaac.

It is told that a student commented to Joseph Campbell, a giant in the study of mythology, that he was tired of the old stories and longed for new ones. Campbell replied that that was fine, "if you have a couple of thousand years to work at it." The Akedah is among the great gifts of the Hebrew Bible. Proposals about its meaning and significance abound: allusions throughout biblical literature, in Rabbinic midrash and the tradition of commentary, philosophic and other, in

2 Or, as in a more tame rendering, "Far be it from you." Fox's translation, quoted here (see Note 2), comes much closer to the Hebrew. If anything, the Hebrew is less tame than Fox suggests. See Fox's footnote to the phrase "heaven forbid": "Lit. "May you have a curse." That seems to me too strong in the context. But the key Hebrew root is "kll," to profane.

3 Genesis 18 The Five Books of Moses, Everett Fox translation: pp. 77-79. (New York Schocken Books, 1983).

4 I am grateful to my wonderful undergraduate teacher, Rabbi Moshe Besdin, z"l (?), for alerting his students to the word, va-yashkem (Gen. 22:3) with its suggestion of an eagerness, a spiritual opportunity. 
Christian treatment of the story and on its reflection in Christian thinking about God's sacrifice of his own son, and in the Qur'an. The text, powerful as it is, is extremely spare. We are thus invited to provide midrash, to fill in gaps, to make sense of the story and of its power.

I propose that we resist starting with the hardest questions. There will be time later for wonder about God's motives, for example. Abraham's thinking - we are not privy to it - is difficult enough. What was he thinking? Did he suffer with the decision? Indeed, was there a decision? What did he tell himself about Isaac, about his commitment to his beloved son, about God's promise that he, Abraham, would be the progenitor of nations?

Before making my proposal, I want to attend to unmistakably significant aspects of the story. Here is one: Abraham's tenderness towards Isaac - and their bond - seem unaffected by the exquisite cruelty of their march. The text encourages us to feel their closeness. It repeatedly reminds us that "the two walked together"; the Hebrew yachdav, "together," is very strong; almost (but not quite), "as one." Indeed even after Isaac asks his father about the missing lamb for the slaughter and Abraham answers that God will provide the lamb - Rashi suggests that at that moment Isaac realizes what's in store - the two walk together, yachdav.

Additionally, Abraham refers to Isaac warmly as "my son." Think about how strange and unlikely this is for a father who - as many would have us believe has already made his decision to kill his son; all is fixed but the terror of the actual sacrifice. For real people--more for those emotionally and spiritually sensitive-such a commitment would naturally prompt a certain distancing of the father from the son.

One of the overarching themes of the Akedah is that of trust, Abraham's trust in God and Isaac's trust in his father (and perhaps also in God). But how are we to understand trust? It is often seen as an expectation that God will see to it that things turn out right, for the best. Many have read the Akedah that way, and there are suggestions in Kierkegaard's Fear and Trembling that such is Abraham's outlook. Although such an outlook would certainly be trusting, I think I see in the Akedah a more subtle, more profound sort of trust. I return to this below.

Turning to Isaac, I see him - in the manner of some teenage boys - as totally trusting in his father, his hero. ${ }^{5}$ Seen this way, the Akedah is among other things

The text does not reveal Isaac's age, licensing speculation, as if one sees the play with different 
a kind of buddy story, more accurately a father-son saga. Until the end - the actual binding of Isaac - and my imagination goes quiet. The Bible never again tells of any interaction between father and son; Abraham seems to return without Isaac who perhaps sets out on his own. ${ }^{6}$ The human costs of God's test are inestimable.

God's initial command is the stuff of nightmares. Could the whole thing be a bad dream, a vision that takes possession of Abraham? It is certainly not presented as such. There are, however, other biblical passages that appear to report actual happenings, only to have some commentators, most famously Maimonides, ${ }^{7}$ take the passages to record prophets' visions.

Maimonides maintains that if an angel, a mal'akh of God, shows up in a narrative, the narrative should be seen as recording the vision of a prophet rather than as a record of actual events. Having announced this as a principle, Maimonides does not apply it to the Akedah, at least not explicitly. Perhaps such an interpretation would be too stunning, too stark, given the central importance of the Akedah in Jewish tradition. But others take this to be Maimonides's view. ${ }^{8}$

In favor of the nightmare interpretation is this: Abraham, having left a culture in which child sacrifice was practiced, enters a new life, a new world. His God is the God of justice, the judge of all the earth, as Abraham calls Him. One night he dreams that things are not at all the way they have appeared; God wants Isaac. This is a nightmare I can imagine having. And the way the story is told, its spare and dreamy quality...

Whether or not Maimonides sees the passage as describing a nightmare, this reading is certainly provocative, and in more than one sense. Of course, if the Akedah is a mere vision, we need not worry about why God would issue such the chilling command. And we could happily bypass the horror of considering Isaac's reaction (not to speak of Sara's) to God's test. But some questions may remain: ${ }^{9}$ what would (or should) someone do in such a circumstance? If one went

age actors and reflects on which comes closest to the truth, "truth" as it were. See Jon Levenson's the Birth and Resurrection of the Beloved Son, p.133, for a discussion of various possibilities, from thirty-seven to twenty-six to fifteen. My Isaac is perhaps fifteen.

6 But see Gen 25:5. Thanks here to Shaul Seidler-Feller.

7 Guide for the Perplexed, Book II, Sec. 42.

8 See Marc B. Shapiro's discussion in Changing the Immutable: How Orthodox Judaism Rewrites Its History (Portland, OR: Littman Library of Jewish Civilization, 2015), pp. 67-71.

9 Or perhaps not. Perhaps, as a matter of methodology, one need not and maybe should not confront such hypotheticals. Perhaps it is like asking, "If God's motivation was evil...? (It is not quite as bad as "If the number 2 were odd, ....") The matter is confusing and may be related to 
along with the command would that be pious or impious? Where does one's faith leave one vis-à-vis such a command?

Still, the proposal is quite radical and I want to explore what to make of the Akedah as usually understood, as a narrative of actual happenings, one that is (somehow) fundamental to the faith. I begin by exploring Abraham's puzzling silence.

A. J. Heschel, throughout his many discussions of prophecy, ${ }^{10}$ denies that the prophets have what we might call propositional knowledge of God. The contrast is with Maimonides's contention that the prophet is a philosopher, that the patriarchs, for example, had philosophic knowledge of God. ${ }^{11}$ Heschel points us in another direction, away from theoretical knowledge and towards a kind of personal familiarity with God. The prophet knows God in a way not available to the rest of us. He "gets" God somewhat in the way that we get one another. Indeed the prophet is in the unique and in many ways uncomfortable position of being acutely sensitive to God and at the same time, to Israel, to the people. The prophet is tuned in, understands and empathizes with their pains and pleasures, their wants and needs, those of God, those of the people. ${ }^{12}$

Instead of reading Abraham as inconsistent - his boldness concerning Sodom and Gomorrah as opposed to his silence in the face of God's command to kill Isaac - we might note the contrast and take it as an indication that Abraham

Wittgenstein-inspired discussions, some years ago, about hypotheticals that change the initial conditions so radically that there is no settled way to resolve the question raised.

10 See e.g., Abraham Joshua Heschel, The Prophets (Jewish Publication Society, 1962), where among many such remarks is this (p. 26): "...the fundamental experience of the prophet is a fellowship with the feelings of God, a sympathy with the divine pathos..." See also sections 24 through 27 of his classic work, God in Search of Man (New York, Farrar, Strauss and Giroux, 1955).

11 Guide for the Perplexed, Book II, Secs. 32, 36.

12 On knowledge of interpersonal nuance: Oliver Sacks, in the title essay (pp. 244-296) in An Anthropologist on Mars (Knopf Publishing, 1995), understands autism - perhaps it is only one variety of autism - as an inability to learn "by hanging around." When one reflects on how we learn so much of what we need for successful negotiation of experience, we learn not by articulation of rules or principles or propositions, but simply by... and here it gets hard to say. How is it that a baby learns to speak? Not by mastering rules or instructions, that is certain. The baby, when things go well, has the equipment that in the course of normal interactions with others allows her to enter our linguistic practice. Or think about how one masters the countless nuances of social life, from the appropriate distance one stands from interlocutors to gestures that signify respect or disdain. One suffering from autism lacks the equipment to learn in this way; what is nowadays called "the autism spectrum" represents various degrees of such deficiency. I speak, of course, as a non-expert. 
sees or understands something that we do not. Surely divine-human communication - whatever it amounts to - is nuanced no less than are our communicative interactions with one another. Something about the interaction with God - the details of which are in any case not available to us - says to him that this is not the time to challenge. ${ }^{13}$

Abraham's silence, then, does not indicate that he shies away from confronting God. Still, he arises early the next morning with eagerness and sets out with Isaac. Does this mean that he has in effect said "yes" to God, that he is committed to doing what God has commanded? If so, I am lost. My sense of Abraham as a giant of faith is at stake. Of course, if that is what the text says, that is what it says. Does it say that?

God's call to Abraham must have induced vertigo, ${ }^{14}$ the world turned upside down, inside out; a moment at which one loses one's bearings. But Abraham's action exhibits an almost peaceful simplicity - walking, one might say, in God's tempo. ${ }^{15}$ How can that be?

Earlier I remarked about trust in God and the way it is often understood, as the belief that things will turn out well, that God will see to it. I suggested that there may be a deeper kind of trust at work here. At the heart of trust, indeed at the heart of faith, is a sense of being grounded in God. Abraham and God are intimates; ${ }^{16}$ that intimacy centers Abraham, he abides in it. It is more than likely that Abraham has achieved the level of intimacy that the Bible, in Deuteronomy $(10: 20,11: 22,30: 20)$, refers to as "cleaving to God." Nachmanides suggests that

13 Eleonore Stump, in Wandering in Darkness (2010), addresses the Akedah in the context of Abraham's life and his spiritual career. In a wonderful turn of phrase, she refers to Abraham's eloquent silence. Her suggestion is that his refraining from objecting to God bespeaks Abraham's understanding of the nature of and reasons for the test that God imposes. However, the idea that God has good reasons for this extreme cruelty is, for me, on a par with the idea that Job's catastrophes are the product of some sound reasons, something far from the suggestion of the beginning of the Book of Job or anything else in Job. I agree, though, and appreciate the suggestion that Abraham's silence is eloquent.

14 Avivah Zornberg explores multiple occasions and dimensions of vertigo in Genesis: The Beginning of Desire (Philadelphia: Jewish Publication Society, 1995). See especially the chapter, "Hayyei Sarah: Vertigo - The Residue of the Akedah."

15 Martin Buber, in Two Types of Faith, trans. N.P. Goldhawk (London: Routledge \& Paul, 1951), p. 22, speaks of acting in God's tempo as an aspect of faith.

16 The verb, "to know," la'daat," conveys intimacy, even sexual intimacy, as when the Bible speaks of Adam knowing his wife. God speaks of Abraham, at the beginning of their as-it-were debate about Sodom and Gomorrah (Genesis 18:19), as someone God has known. 
one so blessed is never without God. ${ }^{17}$ It is as if one has just fallen in love: one walks, as we say, on a cloud, never without a sense of the other's presence.

This, of course, is a very different matter than believing that God will make it right. It is not a trusting that (something is the case); rather trusting in (someone). ${ }^{18}$ One so grounded, so centered, may in fact harbor the thought that God will make it right, that God always makes it right. But not necessarily. Perhaps Abraham, like many of us, has seen enough of life to disabuse him of such optimism. Perhaps his trust, his faith, is more a matter of an unbreakable bond, borne of intimacy; he and God together, come what may. ${ }^{19}$

Abraham's commitment to God - whole and entire - stands alongside his wholehearted love for Isaac. It is difficult to imagine the two coming apart; they seem like interlocking aspects of a deeply religious, deeply human outlook. But God's command rips them apart. We are not told that it threatens to do the same to Abraham. But to know a parent who has lost a child is to know something of what was at stake. The thought of losing a child by one's own hand is so bizarre as to be unthinkable. Whence Abraham's simplicity?

It is, I think, generated by a faith that sustains one in the midst of darkness. Abraham sets off, not knowing where the path will lead, but ready to follow it until the end. He marches, both non-negotiable loves clenched between his teeth, his head down, straight ahead, a moment of transcendent faith. Abraham's spiritual genius - the rules have been left behind - is in part a matter of not confronting the decision prematurely. That would be paralyzing, offering only obsessive anguish.

In philosophy - perhaps in ordinary thinking as well - we tend to overemphasize the role of decision-making in voluntary or intentional action. Of course, people sometimes need to stop and think about what is to be done, to decide which way to go. But most of the things we do are, as it were, smooth, virtually automatic. ${ }^{20}$ We typically function more like well-oiled machines than like creatures whose actions bespeak a discontinuity of choices made.

Abraham's faith - as I am suggesting that we understand it - renders his response to God's command somewhat like the output of a well-oiled machine. Of course Abraham could have refused God's command; alternatively, he could

17 In his commentary on Deuteronomy 11:22.

18 So Jeff Helmreich suggested as the best way to put the distinction I am making.

19 Cf. John Dewey, Chapter 1 in A Common Faith for a parallel point about "moral faith."

20 As Professor Larry Wright has emphasized in many conversations. 
have explicitly agreed to kill Isaac. I do not mean to challenge his freedom to do these things. But his way in the world - including his faith, inseparable from his character - moves him to proceed, clinging to both non-negotiable loves, with the sense that with God's help, as it were, he will know what to do when the time comes. Abraham's way represents the epitome of practical wisdom in the face of excruciating choices.

Ironically, with Isaac's hand in his, Abraham unknowingly reverses the challenge; will God be silent, will He remain silent? God responds by calling off Abraham. Perhaps He has seen enough. Perhaps God's tests - Abraham and Job come forcefully to mind - are tools by which God and the universe allow us to grow in ways otherwise unavailable. ${ }^{21}$

I will close with a reflection on a postponed question, perhaps the most difficult one: how is God's command even remotely consistent with the character of the God of Israel?

First, an approach that I mention primarily to put aside. In the Exodus passages about the redemption of the first-born, God sometimes sounds as if $\mathrm{He}$ wants the first-born (Exodus 22:28-29; Numbers 3:13); other times the text speaks of the redemption of the first born, as if by right they belong to God but that the remedy is symbolic (for example, Exodus 13:13). And in a strange, one of a kind passage in Ezekiel, God, through Ezekiel, speaks of the first-born and of the fact that God's anger with the Israelites prompted him to give them "laws that were not good (Ezekiel 20:25)."22 The topic is vexed; the thought that the God of Israel was sympathetic to child sacrifice is inconsistent with many remarks in the prophetic literature. Still, one might understand the Akedah as depicting God working it out, both wanting child-sacrifice and in the end rejecting the idea. The view is worthy of mention, but there is neither external, say archeological, evidence

${ }^{21} \quad$ Unlike Kierkegaard and many others, I do not see Abraham's central challenge to be moral. Were I asked to kill a child of mine, probably only (much) later would I think about morality. Abraham must think: how can I kill my boy. I cannot imagine that he is thinking, "How can I violate morality?" To be primarily stunned by the violation of morality would be the proverbial one thought too many. What is at stake is rather in the domain of love. Thanks to Harry Frankfurt for the insight that the primary challenge is not moral.

22 See Jon Levenson's The Death and Resurrection of the Beloved Son (Yale University Press, 1993), esp. Chapter 1, "Child Sacrifice in the Hebrew bible: Deviation or Norm?" 
for Israelite child sacrifice, nor clear textual evidence, nor a preponderance of scholarly opinion. ${ }^{23}$

What then motivates God to ask for Isaac? The cruelty of God's command is breathtaking. It is not only the viciousness of asking a father to take his child's life; Isaac is to be a burnt offering. Here is how a burnt offering was to be made: the flesh burned, the skin retained. Later in the Bible we are told of burnt offerings' sweet smell to God. All of this lends credence to - it is almost enough to make one accept - the nightmare interpretation, attributed by some to Maimonides.

There is something awful about comparing horrors, but the Akeidah makes the terror of martyrdom look relatively tame. ${ }^{24}$ Martyrs die b'taharah, in purity, with clarity of purpose and of conscience. Here the world has turned upside down. The Creator who appointed Abraham to bring light and justice to world reminds Abraham of his fatherly love as he asks for Isaac's flesh.

Perhaps the reason for God's command is not to be explained. Accounts in the spirit of theodicy are available, but they lack the scent of truth. There is a tendency among philosophers and theologians (and no doubt other theorists) to shore up theory, "pushing it," defending their views by way of theses that for all their brilliance lack naturalness. Such answers pale in comparison with the questions that prompted them. As with conduct so with thought: straightforwardness, straight-ahead-ness is near the head of the table of virtues.

In that spirit (or so one hopes) I want to transpose the question into a different key. Let us ask instead why the Bible, as opposed to later apologists, is so little interested in protecting God from apparently just criticism, how its extreme openness contrasts strikingly with the defensive posture of later theorists. Some of the reported doings of God are simply appalling. With Abraham of Genesis 18:23-25, quoted at the beginning of this paper, we wish to call it by its right name and to understand how it is possible. It is one thing, bad enough, to hear of how God treats His (and Israel's) enemies, as in the book of Joshua. But with the Akedah as with Job we are speaking of God's beloved. The Bible displays these things apparently without hesitation, with no attempt to explain, or even to soften the appearance of cruelty.

The Bible does not seem to know about God's “omni-properties," His perfections, an idea that comes into semi-official prominence only later, during medi-

23 As Levenson points out.

24 Similarly tame by comparison is the tragedy befalling Job and his family. 
eval times. ${ }^{25}$ In the biblical narrative, God's ways lack perfection; and not only in the ethical domain. God changes his mind, becomes angry, almost petty, is jealous in a very human way, is subject to flattery, and the like.

The biblical imagination seems to comport with a conception of worship at odds with later theory as well as with the sensibility of the other Abrahamic religious traditions. The latter tend to see worship as the adoration of perfection. In the Hebrew Bible, the gap between here and there, between us and God, is certainly maintained but there is also something of the flavor of domestic life, as if we were life partners, sharing good times and bad, triumphs and disasters, subject to anger with one another, sometimes severe, and falling in love with one another time after time.

At the beginning of the Book of Hosea (1:2), God tells the prophet to marry a whore; presumably to convey the sense of what it is like to be married to Israel. ${ }^{26}$ The Song of Songs is poetry of love, emphasizing longing for the other, including sexual longing, and the joys and aches of love. It was understood by the tradition to be a parable about God and Israel. Rabbinic Midrash has God going into exile with the Jews after the destruction of the Temple. God prays, in the Talmudic imagination, that His desire for strict justice will be overcome by his loving, nurturing side. God struggles as do His creatures.

From the perspective of Perfect Being theology, such anthropomorphisms will seem to rob God of what makes him godly. On the outlook I am eliciting from the Bible, it is the Perfect Being conception that robs God of what makes Him godly, including His love for His creatures; it also yields a very narrow conception of worship. The flavor of the biblical conception is illustrated by the following comment on the Mourner's Kaddish. One recites this prayer three times a day for 11 months following a parent's death. Strangely, the prayer never mentions death or the deceased. Instead it is a glorification of God prayer. The comment I came across when I was a mourner, one that transformed the recitation, was that Kad-

25 There are of course biblical remarks that suggest that God is perfect, without flaw; others where a lack of perfection is plain. But the context of biblical literature suggests the sort of perfection that we attribute to our lovers and loved ones, our children for example. During talmudic times, perhaps with the increasing influence of Greek, then Christian, then Muslim thought, one finds increasing doctrinal attention to God's perfection.

See Jeremiah 2:2 for a striking image of the "couple" as newlyweds. 
dish is the mourner's attempt to comfort God for His loss. ${ }^{27}$ There is something very comforting about comforting another. One shares a life with God.

A very different side of Jewish religious sensibility: Elie Wiesel writes ${ }^{28}$ a story about a trial held by three rabbinic inmates of a German concentration camp. God is charged with crimes against His chosen people and is pronounced guilty. Right after the verdict the group adjourns for the evening prayer.

Seeing God in anthropomorphic terms, as with the interpretation of Kaddish mentioned, can be uplifting. And then one gets to Job or the Akedah, or the Holocaust. To the extent that one allows oneself to let the story in, to feel it, one is horrified. That we attempt to repair the wound, to explain God with the suggestion that if it happens there must be a reason, these understandable reactions nevertheless situate us a bit too closely to Job's Comforters. The biblical texts are plain; they do not so much as hint at theodicy.

Perhaps the Bible's unembarrassed directness about God's ways is testing us, but not in a way acknowledged by the theodicies. As Abraham was incredulous at the thought that God might destroy a city in which righteous people lived, perhaps we should allow ourselves to taste the moral horror, to be stunned by these questions that can have no answers. Perhaps this is training in faith, in straightaheadness. Perhaps such training and such faith are the point.

\section{Afterword}

On September 11, 2001, the day of the catastrophe, my wife and I were flying home from London. Hours into the flight I sensed that the plane turned completely around. After a while an announcement was made: the air space over California had been closed and we were heading back to London. There was a buzz among the passengers and the air phones were not functional - what was that about? No one had any idea what had happened. Later we were told that the air space over the US had been closed. More suspense, but still no explanation. We landed in London, sat on the ground for perhaps a half hour; an airline repre-

27 See The Jewish Way in Death and Mourning by Maurice Lamm (Jonathan David Publishers, Middle Village, NY, 1969), p. 149. Lamm attributes the idea to S. Y. Agnon and expands on Agnon's treatment, but Lamm does not comment further on where Agnon addresses the matter.

28 See his play, The Trial of God (Knopf, 1979). The story is based on an incident that Wiesel witnessed as a prisoner in Auschwitz. 
sentative appeared and told us about the New York and Washington, DC terrorist attacks. Our daughter recently had moved to New York City and our son was in DC. Could we have lost one or both of our treasures?

We were beside ourselves. With trepidation, we proceeded through a long corridor into the main terminal. Dominating my thoughts during the endlessseeming walk was Abraham's march, with faith, with his head down, holding on to both loves, not thinking about what lay ahead. In the end we learned that our kids were fine. It was more than gratifying to reflect on what I had learned from Abraham.

\section{Bibliography}

Dewey J., A Common Faith, New Haven, CT: Yale University Press 1934.

Buber M., Two Types of Faith, trans. N.P. Goldhawk, Routledge \& Paul, London 1951.

Lamm M., The Jewish Way in Death and Mourning, Jonathan David Publishers, Middle Village, NY 1969.

Levenson J., The Death and Resurrection of the Beloved Son, Yale University Press 1993.

Shapiro M.B., Changing the Immutable: How Orthodox Judaism Rewrites Its History, Portland 2015.

Stump E., Wandering in Darkness: Narrative and the Problem of Suffering, Oxford University Press 2010.

Zornberg A., Genesis: The Beginning of Desire, Jewish Publication Society, Philadelphia 1995.

\section{Summary}

There is something enormously powerful, even inspirational, about the Akedah story and about Abraham who was, after all, named the Father of Faith. He may be judged as inconsistent - his boldness concerning Sodom and Gomorrah seems 
to contradict with his silence in the face of God's command to kill Isaac. However, we might note the contrast and take it as an indication that Abraham sees or understands something that we do not. Similarly, in the light of these stories it is worth rethinking God's ways and the "strategy" of the Bible. We tend to explain God's Will with the suggestion that if something happens there must be a reason for it - we treat it like a wound that requires mending; these understandable reactions nevertheless situate us a bit too closely to Job's comforters. The biblical texts are plain; they do not so much as hint at theodicy. Perhaps the Bible's unembarrassed directness about God's ways is testing us, but not in a way acknowledged by the theodicies.

Key words: Akedah, Abraham and Isaac, the Bible, God's ways, theodicy

\section{Streszczenie}

\section{Wiara Abrahama}

Jest coś niezmiernie potężnego, nawet inspirującego, w historii Akedah i w Abrahamie, którego bądź co bądź nazwano Ojcem Wiary. Może on się nam wydawać niekonsekwentny - jego śmiałość w sprawie Sodomy i Gomory wydaje się nie do pobodzenia $\mathrm{z}$ milczeniem w obliczu rozkazu Boga, by zabił Izaaka. Ale możemy też, zauważywszy tę uderzającą różnicę w postawie, potraktować ją jako wskazówkę, że Abraham widzi albo rozumie coś, czego my nie widzimy i nie rozumiemy. W świetle tych opowieści warto rozważyć ponownie działanie Boga i „strategię" Biblii. Mówimy zwykle o Woli Bożej, sugerując, że jeśli coś się dzieje, to z pewnością nie bez racji - jakbyśmy mówi o ranie, które musi się zagoić; te reakcje, choć zrozumiałe, niebezpiecznie upodabniają nas jednak do pocieszycieli Hioba. Teksty biblijne są jasne; nie zawierają nawet cienia teodycei. Być może nieskrępowana bezpośredniość, z jaką Biblia przedstawia Boże działanie, jest próbą, ale próbą innego rodzaju niż ta, z którą mierzą się teodycee.

Słowa kluczowe: Akedah, Abraham i Izaak, Biblia, Boże działanie, teodycea 